\title{
STATUTES AS JUDGMENTS: THE NATURAL LAW THEORY OF PARLIAMENTARY AGTIVITY IN MEDIEVAL ENGLAND*
}

\section{MORRIS S. ARNOLD †}

The proposition that late medieval English lawgivers believed themselves to be exercising a declarative function has been so frequently put forward and so widely accepted that it is in danger of being canonized by sheer dint of repetition; ${ }^{1}$ and thus one who would deny the essential validity of that notion bears the virtually insuperable burden of proof commonly accorded an accused heretic. Nevertheless, it will be argued here that natural law notions are attributed to the medieval English legislator with only the slightest support from the sources, and after only the most rudimentary and uncritical analyses of the implications of such an idea. One possible source of confusion lies in the use of the term "natural law" in at least two distinct fashions. For some, the notion is embodied in the principle that all legislation is declaratory of pre-existing rights; ${ }^{2}$ for others, the central idea of natural law is the proposition that some matters are beyond the reach of legislative authority. ${ }^{3}$ It will not be possible here to deal with all the various statements of the argument or its refinements, ${ }^{4}$ but I hope to sketch in outline my reasons for believing the declaratory theory to be generally misconceived and offer some admittedly tentative conclusions.

\section{I.}

The central difficulty faced in an investigation of the legitimacy of the declaratory theory is knowing what medieval English-

- This Article is based on a paper delivered to the American Society for Legal History at Chicago in November, 1974.

$\dagger$ Professor of Law, University of Pennsylvania. B.S.E.E. 1965, LL.B. 1968, University of Arkansas; LL.M. 1969, S.J.D. 1971, Harvard University. Member, Arkansas bar.

I See F. KenN, Knngshit ANd Law In the Mrodle Ages (S. Chrimes trans. 1939). Kern's declaration is the most common statement of the proposition under criticism here. It has been often, and recently, repeated. See, e.g., M. HorwIrz, The Transformation of American Law, 1780-1860, at 16-17 (1977).

2 F. KERN, supra note 1 , at 156-66.

3 E.g., C. McIlwain, The Hrgh Court of Parliament 99 (1910).

4 For a useful survey of the controversy, see J. Gough, Fundamental Law IN English Constitutional Histony 12-29 (1955). 
men were thinking; and unless they tell us directly, we can know their thinking only by examining their deeds. Of the numerous law books written in the thirteenth century, ${ }^{5}$ not one contains a statement indicating an awareness of a declaratory theory of parliamentary enactments. Bracton concerns himself not with whether the law can be changed, but rather with who can change it. ${ }^{6}$ It is true, of course, that most thirteenth-century lawbooks dealt principally with procedural matters and that, for all the modern commentary on Bracton's public law passages, ${ }^{7}$ only a tiny fraction of the De Legibus is devoted to constitutional matters. Still, if natural law theories of legislation had any currency at all in England, it seems odd that Bracton, the extent of whose Romanesque learning is only now becoming apparent, ${ }^{8}$ has nothing to say about them. He can hardly have been unaware of the controversy over natural law notions which consumed much of the time of contemporary divines, canonists, and legists. ${ }^{9}$ A medieval commentator on Bracton has put it well: "[I]n Anglia minus curatur de iure naturali quam in aliqua regione de mundo . . . ."10 (In England less attention is paid to natural law than in any other part of the world.)

While the silence of Bracton and of other thirteenth-century treatise writers is suspicious, it is admittedly inconclusive. Direct evidence having failed, resort must be had to legislative practice in order to discover the medieval English attitude toward enacted law.

5 There are more of these books than is generally realized. See Hazeltine, Preface to Radulphi De Hengham Summae (W. Dunham ed. 1932); Woodbine, Introduction to Four ThIRTEenth Century LAw Tracts I-4 (1910) (containing only a partial list of thirteenth-century treatises on law).

62 Bracton, On The Laws and Customs Of England (De Legrbus) "I, ${ }^{\circ} 55$ (S. Thorne trans. 1968 at 21, 169). Following Justinian (or Azo), Bracton makes the mandatory allusions to natural law. Id. $3 \mathrm{~b}-4$ (S. Thorne trans. 1968 at 26). Nowhere, however, does he speak of the duty of legislation to conform to the dictates of natural law, nor does he attempt to define its content. Moreover, he speaks of the right to self defense as part of the jus gentium. Id. 4 (S. Thorne trans. 1968 at 27). He differentiates between natural law and the jus gentium and furthermore states that civil or municipal law may contradict the jus gentium. In contrast to Bracton's discussion of natural law, there is some very sophisticated analysis by his contemporaries on the Continent about the duty of legislation to conform to natural law, and about what happens when there is a conflict. See A. D'Entrèves, NAtural LAW 37-50 (2d ed. 1970). See also text accompanying notes 67-70 infra.

7 See, e.g., Schulz, Bracton on Kingship, 60 ENG. Hist. Rev. 136 (1945).

${ }^{8}$ See Thome, Introduction to 1 Bracton, ON ThE Laws ANd Customs OF England xxxii-xl (S. Thorne trans. 1968).

${ }^{3}$ See A. D'ENTRÈves, supra note 6, at 37-50.

108 Selden Society, Select Passages From The Works Of Bracton and Azo 125 (F. Maitland ed. 1895) (Maitland describes this commentary as a marginal gloss on Bracton's work taken from a Cambridge manuscript that "seem[s] to [have] come from a man who was at work in the last years of Edward $I$. and the first of Edward II." Id. 123). 


\section{II.}

That English law "changed" in one sense or another over the course of the middle ages is a proposition that none, of course, would dispute.11 More importantly, it is equally clear that conscious breaks with the past were regular features of English legislation from the earliest times. A few examples will make this clear.

Circa 890, King Alfred, while admitting that he had consulted the laws of his predecessors in promulgating his own, stated that "[M]any of those I did not approve of I have annulled . . . ." ${ }^{12}$ His criterion for selection was the "justness" of the laws examined: "[T] hose which were the most just of the laws I found . . . these I have collected while rejecting the others." 13 Moreover, Alfred did not claim his laws were any more permanent than those which preceded them, for he added that, "I cannot tell what [innovations of mine] will meet with the approval of our successors." 14 There are other examples of admitted departures from past legal norms during the Anglo-Saxon period, ${ }^{15}$ but these words of Alfred furnish the clearest and most self-conscious evidence of deliberate change through legislation.

Nevertheless, it remains true that English kings and their advisers usually exhibited a remarkable conservatism. The most hackneyed example of resistance to change is the famous dictum of the Barons at Merton when met with the question of the legitimating force, if any, of a subsequent marriage. One version of that dictum is "nolumus leges Angliae mutare quae usitate sunt et approbatae." 16 That is, "We would not change the laws of England which are customary and approved," or, more forcefully perhaps, "We do not wish to change the laws of England which are customary and approved." It seems quite significant that they did not reject the canonists' notion of post-marriage legitimation with a shrug and a non possumus; it is not their inability to effect a change in the

11 For an assessment of the changes wrought by Edward $I$, see T. PLucknetr, Edward I and Crminal Law (1960); T. Plucknett, Legislation Of Edward I (1949).

12 The Laws of the EarLiest English Kings 63 (F. Attenborough ed. 1922).

13 Id.

$14 I d$.

15 See, e.g., id. 19 (the preamble to the decrees of Hlothhere and Eadric, Kings of Kent, describes those decrees as extensions of the laws of their predecessors); id. 25 (the preamble to the decrees of Wihtred, King of Kent, describes the decrees as additions to the legal usages of the people of Kent).

16 Maitland, Introduction to 1 Bracton's Norebook 115 (3d ed. 1887). See also id. 104-17 (discussing the three extant versions of the phrase). 
law that makes them reluctant, but a dislike for the substance of the change-and for its source. ${ }^{17}$

That legislative changes were not uncommon in the thirteenth century is evident from the most cursory examination of the statute book. The legislation of Edward I is the most fruitful for this purpose, though precedents from the reign of Henry III are not wanting. Innovative and intentional law-giving is a most obvious feature of the statute $D e$ Donis, ${ }^{18}$ which specifically states that the previous condition of the law is the mischief to be undone. ${ }^{19}$ The familiar effects of the statute are worth mentioning here: the donee in fee tail lost his right to alienate and a remedy was given the heir. In effect, the statute converted a fee simple into a life estate, and what was at best a mere expectancy into something like a vested remainder in fee-what kind of fee would be the subject of more debate in the following century. ${ }^{20}$ This was a legislative feat worthy of the most powerful sovereign in the most sovereign of ages.

Another obvious example of what seems to have been intentional and innovative lawgiving is the statute of Quia Emptores. ${ }^{21}$ By this statute the former practice of subinfeudation was forbidden, it being provided that

[F]rom henceforth it shall be lawful to every Freeman to sell at his own pleasure his Lands and Tenements, or Part of them; so that the Feoffee shall hold the same Lands or Tenements of the [Chief Lord of the same Fee, by such Service] and Customs as his Feoffor held before. ${ }^{22}$

The possibility of successfully arguing that this statute was merely declaratory is remote. The field of criminal law provides other examples, such as the creation of seemingly new misdemeanors during Edward I's reign. For instance, the Statute of Westminister II made it illegal to fish for salmon at certain times. ${ }^{23}$ Finally, the Statute of London contains a large number of what now might be

171 F. Pollock \& F. Martland, The History of English Law 188-89 (2d ed. 1968).

18 Statute of Westminster II, 1285, $13 \mathrm{Edw} .1$, preamble \& c. 1, reprinted in 1 Statutes of The REALM 71 (1810).

19 Id.

20 See T. Plucknett, A Concise History of the Common Law 551-57 (5th ed. 1956).

21 Statute Quia Emptores Terrarum, 1290, 18 Edw. 1, reprinted in 1 STATUTES of the REALM 106 (1810).

22 Id.

23 Statute of Westminister II, 1285, 13 Edw. 1, c. 47, reprinted in 1 STAtUTES of THE REALM 94 (1810). 
referred to as municipal regulations. Examples include new rules prohibiting the teaching of fencing ${ }^{24}$ and outlining the qualifications of those seeking to be hostelers and innkeepers. ${ }^{25}$

It is true that much of Edward's legislation was said to be aimed at merely providing a remedy. De Donis, for instance, specifically stated that the King granted the statute because he "perceiv[ed] how necessary and expedient it should be to provide Remedy in the aforesaid Cases." 26

It is also true that abrupt beginnings are very rare in English legal history. For example, subinfeudation was forbidden by local custom in some regions even before Quia Emptores; ${ }^{27}$ and De Donis was anticipated by the availability of the writ of Formedon in very select circumstances before the passage of the statute. ${ }^{28}$ Nevertheless, as Professor Milsom has pointed out, "The statute was not declaratory." 29 It is clear, furthermore, that an entry by an heir in fee tail on an alienee would not have been regarded as permissible before the statute. ${ }^{30}$ Much of Edward's other legislation was intended to provide legal redress where the law had previously supplied none. Chapter 50 of Westminster II notes that some, but not all, of its sections were aimed at eliminating instances "where the Law faileth . . . lest Suitors coming to the King's Court should depart from thence without Remedy." 31 This concern with remedies, however, does not necessarily mean that the legislators' minds were fixed against innovation; in this case it may mean just the opposite-that a new direction must be taken. The realization that a statute created an entirely new and different substantive legal relation finds expression in the common assertion that it is to apply "from henceforth," and in explicit prohibitions against retroactivity. ${ }^{32}$ As Chief Justice Berreford stated in 1305, in a case in-

24 Statutes for the City of London, 1285, $13 \mathrm{Edw}$. 1, $\llbracket 3$, reprinted in 1 STATUTES OF THE REALM 103 (1810).

25 Id. [6. The existence of purely regulatory laws like these are very difficult to explain on natural law grounds. It is hard to see them as other than positive enactments intended to accomplish municipal policies not easily located in natural law.

26 Statute of Westminister II, 1285, $13 \mathrm{Edw} .1$, preamble, reprinted in 1 Statutes of the REALM 71 (1810).

27 See T. Plucknetr, Legislation Of Edward I 5 (1949).

28 Milsom, Formedon Before De Donis, 72 LAw Q. Rev. 391 (1956).

29 Id. 393.

30 See 2 Bracton, supra note 6, at $17 \mathrm{~b}$ (S. Thorne trans. 1968 at 67 ).

31 Statute of Westminster II, 1285, $13 \mathrm{Edw}$ 1, c. 50, reprinted in 1 STAtures of Tre Rearar 95 (1810).

32 The Statute of Westminster II provides: "All the said Statutes shall take Effect at the Feast of St. Michael next coming, so that by occasion of any Offence 
volving what today's judges would call problems of fair warning, "At common law no one knew the law which would be for the future." 33

III.

If, as it is asserted here, there was so much self-conscious innovation in the legislation of the late thirteenth-century, if Edward and his legal advisors had evidently set out to change much that had been clear law before, if the contemporary chronicles record that the King at Westminster had "established very many new laws," 34 how did it happen that the declaratory theory of parliamentary activity has remained so popular in the academic mind? How did it come to pass, as Plucknett puts it, that this paradox has been so long and so brilliantly sustained? ${ }^{35}$

First, a caveat advanced before may be usefully repeated herethe thing to be determined is how medieval Englishmen who concerned themselves with such matters conceived of the job Parliament was doing, and not the job itself. Even a society which clings devotedly to a natural law theory of parliamentary activity can effect the most fundamental changes by claiming that every change accomplishes no more than a return to more pristine, and therefore more correct, beginnings. In other words, the common law could be said to have strayed from the true path and a statute was therefore required to set it right. Alternatively, it might be argued that natural law had never been embodied in previous custom or statute, and that it is only through the new enactment that natural right is vindicated. So all of Edward's innovations, and indeed those of the Anglo-Saxon kings, can be explained away in this fashion. ${ }^{36}$ By relying on such reasoning, even the provisions against retroactivity in Edward's statutes can be explained: a person ought not to suffer because he has relied justifiably on a previous, though erroneous, state of the "law." Such provisions, the argument would

done on this side the said Feast, contrary to any of these Statutes, no Punishment ... shall be executed upon the Offenders." Id. On the retroactivity of medieval English statutes generally, see T. Putchnetr, Statures and Them Interpretation In The First Half OF The Fourteenth Century 113-120 (1922).

33 Rote v. Benet de C., Y.B. Pasch. 32 \& 33 Edw. 1, 480 (1305) (RoLls Serues) (author's translation).

34 F. Powicke, The Thmieknta Centuny 369 (2d ed. 1962) (quoting the Norwich chronicler); see id. 368-80.

35 T. PluCKNETr, supra note 27 , at 6 n.1.

36 The fact that Alfred, see text accompanying note 12 supra, in picking among his predecessors' laws employed the criterion of "justness" arguably indicates that he thought it was their "just" character, and not his will, that gave them legitimacy. 
run, merely prevent forfeitures which would otherwise befall innocent people. In other words, a defense of reasonable mistake of law is embodied in the statute. The statute De Donis, for example, is made prospective in its application not because it was not always the law, but because a retroactive application would be unfair and amount to a form of official entrapment. Therefore, even the most striking innovations of medieval parliaments can be made to look like what modern lawyers would call "prospective overruling."

To repeat, such arguments could be advanced to defend the declaratory theory of statutory enactments, and some of these ideas have in fact been employed. Most, however, have not, and for good reason. The notions outlined above are rather sophisticated, and while it ought not be doubted that Edward and his advisers were intellectually capable of entertaining them, it is not easy to believe that they did so without leaving a trace in the literature. The only alternative to this contorted analysis, it is submitted, is to abandon the theory of a declaratory Parliament entirely, and substitute for it an assembly bent on preservation, not because it was in some sense necessary or inevitable, but because it was desirable. Advocates of a contrary view may still argue, nonetheless, that members of Parliament saw their actions as those of a court, declaring the law, rather than a legislature, capable of creating and changing it. Upon close analysis it appears that that argument, too, is based on misperceptions.

\section{IV.}

The fact that Parliament was a court, even primarily a court, has led some to believe, and to say, that it was only a court and that its members saw little or no difference between adjudication and legislation. ${ }^{37}$ Such opinions find apparent support from the occasional assertions in the Year Books that acts of parliament are judgments. ${ }^{38}$ These assertions have been seized upon as proof that natural law theory lay behind all parliamentary activity-that, in other words, statutes and judgments were regarded as identical.

Even the most cursory examination of the cited cases is sufficient to establish that this claim is erroneous. In none of them is it stated that a statute is a judgment; only an act, or some acts, are

37 See Barraclough, Law and Legislation in Medieval England, 56 LAw Q. Rev. 75, 76-83 (1940); cf. Thorne, Introduction to A Discounse Upon tren Exposicion and Understanding of Statutes 9-10, n.9 (S. Thorne ed. 1942) (stating that "statutes [were not] regarded as quite different from the judgments, records, and fines customary [in Parliament]").

${ }^{38} \mathrm{See}, e . g .$, those cases cited in note 39 infra. 
said to be judgments. ${ }^{39}$ The word "act" is not used to describe a parliamentary product until the late 14th century, and then only rarely. When it appears, it is employed in a quite vague and general fashion, much the same way as it is used in the "Acts of the Apostles" or the "Acts of the Privy Council." "Acts" in these instances simply means a narrative of things said and done. This definition has absolutely nothing in common with the word's modern connotation of a product of legislative effort. ${ }^{40}$ Over the course of time the meaning of the term came to include statutes, and there are a few, rare examples of its employment in this fashion in the fifteenth century.41 For the most part, however, it is reserved for describing activity other than general legislation. Rather, "act" is most often used to describe either the outcome of petitions filed by individuals, or filed on their behalf, against other individuals with a view to adjusting the parties' private rights, or grants made by the King to certain individuals at their urging. It is not surprising, therefore, that the results of such petitions should be regarded as mere judgments.

An example will make this clear. In the third year of the reign of Edward IV, Robert Woodlark (the Year Book calls him "Wodlac"), the Principal of what later became St. Catharine's College, Cambridge, was sued by the Warden of Merton College, Oxford, for wrongful entry and detainer. ${ }^{42}$ The property in dispute included Merton Hall in Cambridge. Woodlark pleaded in bar an Act of Parliament (actually letters patent of the King issued with the advice and consent of Parliament) granting the lands in question to his predecessor; and on this plea a demurrer was joined.

Littleton, arguing for the plaintiff, claimed the bar was insufficient, first of all, because it failed to give the plaintiff "color" of title-that is, it failed to show how the plaintiff was claiming the land and why the claim was bad. (In this period, most lawyers thought it was necessary for all pleas in bar in trespass cases where the title of land was in question to anticipate the plaintiff's claim in this fashion.) Furthermore, he said, even if color had been

39 In re Annuite, Y.B. Hill. 21 Hen. 7, f. I, pl. 1 (1505); Provost \& Escholiers de Camb. v. Vicair de Camb., Y.B. Trin. 7 Hen. 7, f. 14, 15, pl. 1 (1491); Sewer v. Wodlac, Y.B. Trin. 3 Edw. 4, f. 1, 2, pl. I (1463) (acts of Parliament declared "the highest record [i.e., judgment] that there is in law"); Chedder v. Broke, Y.B. Mich. 8 Hen. 4, f. 12, 13, pl. 13 (1406) (ordinance of Parliament pertaining to a particular assault and battery said to be a "judgment").

40 See generally $\mathrm{H}$. Gray, The Influence of the Commons on EarLy LEgisLation 387-404 (1932).

41 For an early example, see Chedder v. Broke, Y.B. Mich. 8 Hen. 4, f. 12, 13, pl. 13 (1406).

42 Sewer v. Wodlac, Y.B. Trin. 3 Edw. 4, f. 1, pl. I (1463). 
given, it might be that some events had occurred after the Act which would have tolled the defendant's entry, and such events ought to be presumed to have occurred unless the defendant shows the contrary. ${ }^{43}$

The defendant replied that color was unnecessary in this case and the Act itself was a sufficient bar; for the plaintiff was "a party and privy to the record [judgment] and it will bind him as much as if we had pleaded a recovery [in a court of law] of the same land ... against the plaintiff or his predecessor by the defendant or his predecessor . . . " 44 The plaintiff is bound by this judgment, "is party and privy to this record," because "everyone is privy to an Act of Parliament." 45 So, Woodlark's argument continued, the plea is prima facie sufficient unless the plaintiff could show some title accruing after the Act which would bar the defendant's right or toll his entry. ${ }^{46}$ This argument is simply that the judgments of parliament in these kinds of land cases are, to use modern terminology, in rem, and thus conclusive against everyone. The judgment was the "highest record" known to the law and determined title, not just between certain litigants and their privies in the usual sense, but in the abstract. Only one judge of the four whose opinions are noted was inclined to give this argument any force, and he merely thought the Act raised a presumption that nothing had occurred subsequent to it to bar the defendant's claim or action. ${ }^{47}$ It would be up to the plaintiff to show by way of rejoinder if that were true.

Littleton was to have the better of the argument, however, and proceeded to demolish the defendant's position. He simply accepted the view that he, like everyone, was privy to this judgment, but argued that once it, like any other judgment, had been executed, it lost its force; and since the defendant's predecessor had been seised by virtue of it, it was no longer of practical effect. He analogized the Act to a recovery against his grandfather in an ordinary law court which had been executed against his grandfather; its bar would extend to him only if it appeared that he was claiming by inheritance from his grandfather. Because nothing of that sort was alleged in the plea in bar he argued that his action ought not to be concluded. 48

43 Id. at f. 2.

44 Id. (author's translation).

45 Id. (author's translation).

$48 \mathrm{Id}$.

$47 I d$. at f. 5 (Ardern, J.).

48 Id. at f. 2. 
Although there was no decision on the demurrer, it is abundantly clear from the discussion that followed that Littleton had won the court over to his characterization of the Act. Indeed, all Littleton had done was to accept his opponent's characterization of the Act and turn it against him. He had done this brilliantly, showing a quickness in the midst of a very technical difficulty which was remarkable. But the perimeters within which the discussion took place were unremarkable and ordinary. What had lain behind the Act pleaded in bar was a dispute between two Royal Colleges. After that dispute was settled in Parliament all titles previous to the Act were barred, that is, the judgment was in rem. (The in rem effect of the Act may actually amount to no more than a restatement of the rule that one may not inquire into the validity of Royal grants.) Subsequent titles, however, were not barred because all the Act accomplished was to quiet title in the winning party in the abstract sense. It was, in other words, a private Act aimed at adjusting private rights, and was no more a statute in the usual sense than a nineteenth-century Act granting a divorce. There is nothing extraordinary in this, and no suggestion whatsoever is made that a statute of general effect and prospective applicability was in any way similar to a judgment. Viewed in this light, Littleton's statement that "if an Act of Parliment be once executed it will not again be put in execution," 49 otherwise incomprehensible, becomes intelligible. Obviously a statute would be "put in execution" until it was repealed. Indeed, the word "statute" is never employed in the argument, and this omission is not likely to have been accidental.

The proposition that the difference between statutes and judgments was much more than dimly perceived finds further support in the 1399 Parliament Rolls of Henry IV. ${ }^{50}$ In the Parliament held that year the commons presented an unusual petition which they prefaced, as the rolls are careful to note, with a request for freedom of speech, although the general grant of that liberty had already been made. ${ }^{51}$ The substance of the petition was this: that "since judgments of the parliament belong solely to the King and the Lords, and not to the commons . . ." the commons therefore prays "that no record be made in Parliament against the said commons to the effect that they are or will be parties to any judgments given or

49 Id. at f. 7 (author's translation).

503 Rotuli Parluamentorum 427 (circa 1783).

51 The original prayer for the liberty of free speech is recorded in 3 Rotuli Parliamentorum, supra note 50, at 424 . 
'to be given thereafter in Parliament." 02 The King answered, through the Archbishop of Canterbury, that the commoners are mere petitioners and plaintiffs and that the King and the Lords have the right of giving judgment. But, the Archbishop says, "with regard to making statutes, grants and subsidies, or such similar things to be made for the common profit of the Realm, the King wishes to have their advice and consent." ${ }^{53}$ In other words, judgments were to be rendered by the King and the Lords, those learned in the law; but the enactment of statutes, laws applicable to everyone, required the consent of the commons.

Statutes and judgments were not only regarded as different in terms of who had the power to promulgate them; they were also viewed as having different effects. The so-called "statute" of William Butler ${ }^{54}$ presents a very interesting example. In 1291 Butler brought a writ of waste complaining of acts done in his ancestor's time, and an objection was taken that there was no cause of action in anyone but the ancestor. The Justices disagreed on the questions presented, and the matter was referred to Parliament. There the dispute was settled in favor of Butler, and it was ordained that this result be "from henceforth . . . strictly observed." 55 In 1315 the effect of this parliamentary act was questioned, and Chief Justice Berreford refused to regard it as a statute, probably because it was not sealed. ${ }^{56}$ Viewed as a judgment he held that it was entitled to no weight because it was wrongly decided. He explained:

It was once said by Sir Henry of Bracton that non exemplis set racionibus adjudicandum est [one ought to decide cases in accordance with reason not precedents]; and what you allege to be a statute never had statutory authority. ${ }^{57}$

In other words, if this parliamentary proceeding had resulted in an effective statute, it would have been followed in subsequent cases. As it was not a statute, however, it could only be a judgment, and there being no doctrine of stare decisis, the court was free to ignore this judgment because it had been erroneously rendered. In the absence of a statute, right reason determined the outcome of a case,

52 Id. 427 (author's translation).

" 53 Id. (author's translation).

54 Statute of Waste, 1291-92, 20 Edw. 1, reprinted in 1 Statutes of the REALM 109 (1810).

55 Id. 110 (author's translation).

56 Cayley v. Tattershall, Y.B. Pasch. 8 Edw. 2, f. 273 (1315), reported in 41 SELDEN Socierty 116 (1924).

57 Id. at 118 (author's translation). 
not precedent. A statute had a future effect; a judgment, even one rendered by Parliament, did not.

\section{V.}

If, as it has been argued here, the occasional equation of acts of Parliament with judgments is not so remarkable as it might at first seem, the proponents of the natural law theory of Parliamentary activity are left virtually without evidence to support their thesis. There is, however, one early fourteenth-century case which may be interpreted to support that idea, ${ }^{58}$ although it has never before been marshalled for such a purpose. It seems appropriate to consider it here.

In Aumeye v. Abbat, decided in 1305, the great Chief Justice Ralph de Hengham suggested that the Statute of Marlborough, ${ }^{59}$ enacted in 1267, should prevail over the Statute of Westminster II, enacted eighteen years later. ${ }^{60}$ "One often sees," said Hengham, "one statute undo another." 61 This dictum earned for Hengham the amused condescension of a later generation of commentators ${ }^{62}$ how could he have been so foolish as to think that an earlier statute could repeal a later one? Yet it is possible that Hengham had hold of a thought that has escaped the commentators. Hengham, in 1307, was seventy years old, or thereabouts, ${ }^{63}$ and his dictum may reflect the confusion which an earlier and more primative legal tradition felt when confronted by two conflicting statutes: if statutes are merely authoritative declarations of what the law "is," and therefore "always has been," how does one reconcile two obviously irreconcilable propositions? ${ }^{64}$ Of course, even the most devoted disciple of the natural law theory need not reach Hengham's conclusion, for one could attribute to parliament the sole and exclusive power of declaration, and could reason just as easily that the latter declaration should prevail over the former. This is only one way out of the

58 Aumeye v. Abbat, Y.B. Mich. 33 Edw. 1, 79 (1305) (Rouls SERIEs).

59 Statute of Marlborough, 1267, 52 Fen. 3, c. 9, reprinted in 1 Statutes of THE REALM 21-22 (1810).

60 Statute of Westminster II, 1285, $13 \mathrm{Edw} .1$, c. 2, reprinted in 1 STATUTES of THE REALM 72-73 (1810).

61 Aumeye v. Abbat, Y.B. Mich. 33 Edw. 1, 79, 83 (1305) (Rolls SERues) (author's translation).

62 See T. Plucknetr, supra note 27, at 73.

63 See Dunham, Biographical Preface to Radulfer De Hengeam Summae, supra note 5, at xlv-xlvi.

64 For a discussion of the implications of the declaratory theory of legislation, see P. Stein, Regutane IURIS 19-25 (1966). 
dilemma, however, and is not at all a necessary corollary to the declaratory theory.

Whatever Hengham's thought may have been, if any, it is clear that it was not shared by his contemporaries. When Richard II was deposed later in the century, one of the complaints against him was that he had ignored the principle that statutes were binding "donec auctoritate alicuius alterius Parliamenti fuerint specialiter revocata" ${ }^{05}$ (until they are specifically revoked by the authority of some other Parliament). Clearly, then, statutes were not regarded as simply declaratory in the fourteenth century, and Hengham's dictum, whatever it may have meant, commanded no respect. Indeed, Geoffrey Scrope, arguing in a case five years later, was astonished by it.68

\section{VI.}

Turning momentarily from consideration of natural law in medieval England to an examination of contemporary literature produced by continental writers, the contrast is quite striking. The writings of canonists and divines will be ignored in order to avoid criticisms of irrelevance and assertions that their writings were purely theoretical and without practical secular effect. Consider instead the famous legist Baldus. In his commentary on DigesT 1.1.3, de Iustitia et Iure, Baldus discussed the right to self defense, and put the case of a statute which makes it lawful to kill an outlaw. ${ }^{67}$ Would such a statute make it unlawful for the outlaw to defend himself? Baldus concluded that it would, as a matter of statutory construction, and then went on to consider whether such a statute would be void as an interference with natural law. He stated that the right to defend oneself is part of the natural law and that "natural law cannot be abridged by statute." 68 On the other hand, Baldus noted that although "natural law cannot be abrogated" by statute, some felt that it could be "covered up," or "veiled" as he put it, for so long as the statute endures. Recognizing a difference of opinion among commentators on this issue, Baldus indicated that proponents of the "statutory veil" theory would, in the example under consideration, support their view by resort to the principle that one may not resist a person who acts under authority of law. ${ }^{69}$

653 Rotuli Partianentorum, supta note 50, at 419.

66 Hauterive v. Painel, Y.B. Mich. 4 Edw. 2 (1310), reported in 22 SerdeN Society 56, 57-58 (1907).

B7 1 B. Ubatdi, OpERA OMNIA 10 (1707).

68 Id.

69 Id. 
Discussions of this sort are simply absent from English law books. ${ }^{70}$ It seems probable that the concepts employed were absent as well from the minds of medieval English lawyers. In the sixteenth century, when lawyers began to have closer ties with the universities and, therefore, with the learned laws, natural law ideas began to appear in their treatises. As a result, Christopher St. Germain and John Perkins were able to produce books so superior to Littleton's that comparison is painful. ${ }^{71}$ Does it not seem preferable to place the advent of natural law theories in England in the sixteenth century, when unusual social and economic pressures caused a parliament and a king to interfere in an almost unprecedented fashion with long-standing common law arrangements? 72

\section{VII.}

In the England of the middle ages, there is no indication that legislation was thought of as having to conform to any particular standard. It is true that, with the exception of Edward I's reign, there were very few changes wrought in the substantive law during the period. The criminal law, the law of contracts and torts, and to a lesser degree the law of property, remained virtually untouched by legislative intervention. But it seems foolish to attribute that fact to a necessity to conform to some external standard, when such an explanation is at odds with the evidence, and when to adhere to it requires contorted analyses. There are alternative explanations for the relatively static nature of medieval law which are more readily supported, and which do not require the imputation of a legal sophistication to the medieval English mind that it almost surely did not have. The most plausible of those alternatives is to attribute the observed changelessness to conservatism, and to see the reluctance to legislate as a reflection, not of a perceived inability, but of a simple lack of desire.

Most medieval obligations derived their force from longstanding common law arrangements and not from statutory authority,

70 Bracton, for example, never asserted that legislation must conform to natural law. As a result, he never concerned himself with what should be done if a conflict arose. See note 6 supra.

71 Compare J. Perkins, A Proftable Book (1528) (Greening trans. 1827); 91 Selden Soctety, St. German's Doctor and Student (1523) (T. Plucknett \& J. Barton eds. 1974) with T. LITtLeton, Tenures (1481) (Tomlins ed. 1841).

72 Circa 1465, Sir John Fortescue wrote a book suggestively entitled De Natura Legis Naturae (On the Nature of the Law of Nature). This volume, however, was concerned with a narrow political question (the succession to the English throne), was not circulated during the fifteenth century, and was not even printed until 1869. It is clear that Fortescue's book had no impact on English legal thought. See Fortescue, On the Nature of the Law of Nature, in Sin John Fortescue, KNIGer, His LIFE, Works, AND FAMIIY Hrstory (T. Fortescue, ed. 1869). 
but this is more easily seen as the product of satisfaction on the part of the classes with real political influence than as the result of disablement. There are some very rare references in Parliamentary discussions to the "law of the land" in a way that makes it clear that something like fundamental law is meant. However, it is clear that these references were made in the context of Parliament's adjudicatory function, and have to do with procedural due process rights (like a defendant's right to be notified with some precision of a plaintiff's claim) which no one would think of trying to alter by legislation in any event. ${ }^{73}$ The resort to ordinary ideas of fairness in settling disputes between individuals in a court room is unremarkable, indeed it was almost surely a regular feature of medieval jury trial. The fund of shared assumptions on which medieval jurors could draw to decide cases, a kind of natural law, was what made that trial system workable. ${ }^{74}$ But the existence of these shared assumptions sheds no light upon the medieval perception of the nature of those few substantive statutes that were in fact passed; nor is it right to derive from the presence of this common fund a resistance to change attributable to any higher ideal than a mere desire to keep things as they were. The point made here is so far mainly destructive, but it seems an improvement over the continued acceptance of a theory whose supporting evidence is embarrassingly absent.

73 See, e.g., Goldington v. Bassingburn, Y.B. Trin. 3 Edw. 2, f. 81 (1310), reported in 20 SELDEN SOCNETY 194, 196 (1905) (Berreford, C.J., relating such an instance from the reign of Edward I).

74 See generally Amold, Law and Fact in the Medieval Jury Trial: Out of Sight, Out of Mind, 18 AMr. J. LEGal Hist. 267 (1974). 